\title{
4-weeks Dynamic Balance training fails to improve ankle and knee joint position sense
}

\section{4 haftalık dinamik denge antrenmanı ayak bileği ve diz eklemi pozisyon algılama hissini geliştiremedi}

\author{
Mutlu Cuğ ${ }^{1}$, Eriik A. Wikstrom² $^{2}$
}

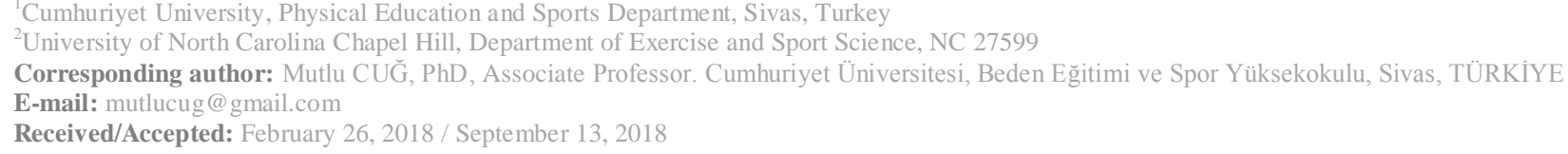

\section{SUMMARY}

Objective: Research clearly shows that balance training improves balance and reduces recurrent injuries. However, the existing data is inconclusive about the effect of balance training exercises on proprioceptive outcomes. While some studies have reported positive effects of balance training on position sense other have reported insignificant findings. For that reason the purpose of this study was to determine if a dynamic balance training program centered on the use of unstable surface exercises can improve lower extremity joint position sense.

Setting: University Research Laboratory

Participants: Twelve healthy men (age: $22.5 \pm 4.58$ years, height: $181.58 \pm 7.57 \mathrm{~cm}$, weight: $85.25 \pm 10.67 \mathrm{~kg}$, BMI: $25.87 \pm 3.01 \mathrm{~kg} / \mathrm{m}^{2}$ ) and 16 healthy women (age: $20.87 \pm 3.4$ years, height: $164.13 \pm 6.15 \mathrm{~cm}$, weight: $63.75 \pm 13.3 \mathrm{~kg}$, BMI: $23.53 \pm 3.94 \mathrm{~kg} / \mathrm{m}^{2}$ ) volunteered to participate.

Intervention(s): All participants underwent a total of 12 supervised training sessions over a 4-week period of time with each session lasting about 30 minutes. The specific exercises that were performed during each training session included: 1) hop to stabilization onto and off of a BOSU ball in four directions (anterior, lateral, anteriomedial, and anteriolateral; 2) mini-squats on a BOSU ball while in a single limb stance; 3) unanticipated reach sequences while stabilizing on a BOSU ball in a single limb stance; and 4) static single limb stance on a BOSU ball.

Main Outcome Measure(s): Ankle joint position sense and knee joint position sense were assessed by a passive reproduction of passive positioning protocol. Target angles of $10^{\circ}$ and $20^{\circ}$ of inversion were used for ankle joint position sense; $30^{\circ}$ and $45^{\circ}$ of knee flexion were used for knee joint position sense assesment. Average absolute error for the dominant limb quantifed joint-position sense.

Results: At the end of 4 weeks dynamic balance training program centered on the use of unstable surface, absolute error score for ankle inversion at $10^{\circ}$ improved from $2.29 \pm 1.61$ to $2.09 \pm 1.86$, knee flexion at $30^{\circ}$ improved from $5.07 \pm 2.78$ to $4.80 \pm 2.55$, and knee flexion at $45^{\circ}$ improved from $4.12 \pm 2.19$ to $3.87 \pm 2.25$. However, this improvements were not significant $(\mathrm{p}>0.05)$

Conclusions: There were improvements noted (absolute error decreased for $10^{\circ}$ of inversion and $30^{\circ}$ and $45^{\circ}$ of knee flexion) despite the lack of significant differences and small effect sizes with $95 \%$ CIs that crossed 0 . The lack of a significant improvement in absolute errors scores could be due to methodological considerations, participant characteristics and/or a training volume dose response.

Keywords: Ankle joint position sense, Knee joint position sense, BOSU ball, Balance training 
ÖZET

Amaç: Çalışmalar denge antrenmanının denge antrenmanını geliştirdiğini ve tekrar eden sakatlıkları azalttı̆̆ı net bir şekilde ortaya koymuştur. Bununla beraber denge antrenmanının proprioseptif çıktılar (pozisyon algılama hissi) üzerine etkisi halen tartışmalı bir konudur. Bazı çalışmalar denge antrenmanının pozisyon algılama hissi üzerine pozitif etkilerini bulurken diğerleri anlamlı olmayan sonuçlar bildirmişlerdir. Bu nedenle bu çalışmanın amacı hareketli zemin antrenmanları kullanılarak yapılan dinamik denge antrenmanlarının alt ekstremite pozisyon algılama hissi üzerine etkisini araştırmaktır.

Çalışma Ortamı: Üniversite Araştırma Laboratuvarı

Katılımcılar: Yirmi sağlıklı erkek (yaş: $22.5 \pm 4.58$ y1l, boy uzunluğu: $181.58 \pm 7.57 \mathrm{~cm}$, vücut ağırlığı:85.25 \pm 10.67 kg, BMI: $25.87 \pm 3.01 \mathrm{~kg} / \mathrm{m}^{2}$ ) ve 16 sağlıklı kadın (yaş: $20.87 \pm 3.4$ yıl, boy uzunluğu: $164.13 \pm 6.15$ cm, vücut ağırlı̆̆ı: $63.75 \pm 13.3 \mathrm{~kg}$, BMI: $23.53 \pm 3.94 \mathrm{~kg} / \mathrm{m}^{2}$ ) çalışmaya gönüllü olarak katılmıştır.

Yöntem: Bütün katılımcılar 4 hafta boyunca bir antrenman seansı 30 dakika süren toplam 12 antrenmana katılmışlardır. Her antrenman seansında uygulanan spesifik egzersizler; 1- Dört yönde (anterior, lateral, anteriomedial ve anteriolateral) Bosu topunun üzerine tek ayakla zıplama-dengeyi sağlama ve başlangıç pozisyonuna tek ayak geri zıplama, 2- Tek ayak üzerinde mini-squat hareketi, 3- Bosu üzerinde tek ayak üzerinde dururken rastgele belirtilen hedeflere dokunma, 4- Bosu üzerinde statik olarak dengede durma

Ölçümler: Ayak bileği ve diz eklemi pozisyon algılama hissi, pasif pozisyonlanma protokolünün pasif tekrarı yöntemiyle ölçüldü. Ayak bileği ölçümlerinde hedef açı inversiyon pozisyonunda $10^{\circ}$ ve $20^{\circ}$ olarak, diz eklemi ölçümlerinde ise diz fleksiyondayken $30^{\circ}$ ve $45^{\circ}$ olarak belirlendi. Dominant bacağın mutlak ortalama hata değeri eklem pozisyon algısının değerlendirilmesinde kullanıldı.

Bulgular: Hareketli zemin antrenmanının temelini oluşturduğu 4 haftalık dinamik denge antrenmanının sonunda mutlak hata skorları ayak bileği $10^{\circ}$ inversiyon için $2.29 \pm 1.61^{\circ}$ 'den $2.09 \pm 1.86{ }^{\circ}$ 'ye, diz eklemi $30^{\circ}$ fleksiyon $5.07 \pm 2.78^{\circ}$ ' den $4.80 \pm 2.55^{\circ}$ 'ye, diz eklemi $45^{\circ}$ fleksiyon pozisyonu için $4.12 \pm 2.19^{\circ}$ ' den $3.87 \pm 2.25^{\circ}$ ' ye gelişse de bu gelişimler istatistiksel olarak anlamlı bulunmamıștır ( $\mathrm{p}>0.05)$.

Sonuç: Ayak bileği $10^{\circ}$ inversiyon ve diz eklemi $30^{\circ}, 45^{\circ}$ fleksiyon pozisyonları için gelişimler gözlense de \% 95 güven aralığında etki büyüklüğünün "küçük" olarak bulunmuştur. Mutlak hata oranında anlamlı bir gelişim gözlenememesinin nedenleri çalışmanın metodolojisi, katılımcıların özellikleri ve antrenmanın doz-etki cevabından kaynaklı olabilir.

Anahtar sözcükler: Ayak bileği eklemi pozisyon algilama hissi, diz eklemi pozisyon algilama hissi, bosu topu, denge antrenmani.

\section{INTRODUCTION}

Ankle and knee injuries are among the most common injuries in sports and daily life ${ }^{1}$. Reported injury cases range from 2.2 sprained ankles per 1,000 person in each year in the United States of America to 5.3-7.0 sprained ankles per 1,000 person-years in Europe ${ }^{2}$. More than two million knee injuries have been reported US emergency, annually ${ }^{3}$. Persons with a previous ankle ${ }^{4}$ and knee injuries are more susceptible to repeated injury and chronic instabilities 5 . It has been reported that $32 \%$ to $74 \%$ of individuals with a previous history of ankle sprain have episodes of "giving way," recurrent sprains, and residual symptoms such as swelling, pain, feeling of instability ${ }^{6}$. Joint proprioception is thought to be essential for appropriate biomechanics and joint stability as proprioceptors provide sensory feedback neccessary to adjust movement patterns 7. Musculoskeletal injuries are known to impair joint position sense, an adaptation thought to contribute to the increased risk of recurrent injury 8 .

As a result, research has focused on eliciting improvements in proprioception in order to subsequently improve biomechanics and to prevent injury ${ }^{9}$. Balance training programs are frequently used in an effort to improve proprioception. Many of these protocols incorporate unstable platform exercises, such as with the use of a BOSU ball. The use of these unstable exercises is thought to better train the proprioceptors at providing quick and accurate feedback for the maintenance of postural control under variable conditions ${ }^{10}$. Theoretically, 
balance training and more specifically, unstable surface training, should improve both balance and proprioception. On the other hand Kiers et al ${ }^{11}$ noted that balance exercises using unstable surface may not have provided appropriate stimulus for ankle proprioception. Research clearly shows that balance training improves balance and reduces recurrent injuries ${ }^{12}$. However, the existing data is inconclusive about the effect of balance training exercises on proprioceptive outcomes. While some studies have reported positive effects of balance training on position sense ${ }^{13-15}$, other have reported insignificant findings ${ }^{16-18}$. For example, Waddington et al ${ }^{19}$ reported that 8 weeks of wobble board exercises result in better ankle joint position sense when compared to jump landing training. It has been hypothesized that the uncreased joint stiffness generated during the landing phase of dynamic balance exercises may limit gains in proprioceptive acuity ${ }^{20}$ relative to static balance training exercises (ie wobble boards). Increased stiffness may overload the periperhal proprioceptors and therefore limit joint position sense gains despite improvements in postural control.

Therefore, the purpose of this study was to determine if a dynamic balance training program centered on the use of unstable surface exercises can improve lower extremity joint position sense.

\section{MATERIAL AND METHODS}

The effectiveness of 4 weeks balance training was assessed by using pre to post design. Dependent and independent variables in the present study were ankle inversion JPS at $10^{\circ}, 20^{\circ}$, knee flexion JPS at $30^{\circ}, 45^{\circ}$; and four weeks balance training, respectively.

\section{Participants}

Twelve healthy men (age: $22.5 \pm 4.58$ years, height: $181.58 \pm 7.57 \mathrm{~cm}$, weight: $85.25 \pm 10.67$ kg, BMI: $25.87 \pm 3.01 \mathrm{~kg} / \mathrm{m}^{2}$ ) and 16 healthy women (age: $20.87 \pm 3.4$ years, height: $164.13 \pm$ $6.15 \mathrm{~cm}$, weight: $63.75 \pm 13.3 \mathrm{~kg}$, BMI: $23.53 \pm$ $3.94 \mathrm{~kg} / \mathrm{m}^{2}$ ) volunteered to participate. This inveistgation is part of a larger study on the effects of balance training ${ }^{21}$.

Inclusion criteria for all participants required that they be between the ages of 18 and 35 and be recreationally active, which was operationally defined as performing at least three aerobic exercise sessions per week for at least 90 minutes. Additionally, participants must have been free from: acute musculoskeletal injuries and concussions for at least 3 months prior to enrollment in the study, free from chronic musculoskeletal conditions, and visual, vestibular (e.g. vertigo), or sensory conditions (e.g. diabetes) that would negatively impact sensorimotor function. Eligibility information was collected with a questionnaire and follow-up interview before participants read and signed an approved informed consent form that was approved by the university's ethics board.

\section{Pre and Post Test Assessments}

In order to assess ankle joint position sense, a passive reproduction of passive positioning protocol was used. In passive reproduction of passive positioning, subjects were asked to match the target angle while the limb was moved by the dynamometer passively. Target angles of $10^{\circ}$ and $20^{\circ}$ of inversion were used. These angles were based on a recent meta-analysis demonstrating the ability of these positions to discriminate between groups with known proprioceptive deficits 8 . Each participant was positioned on a Biodex isokinetic dynamometer (Biodex Medical Systems, Shirley, New York, USA) chair, with the calf of the tested leg resting on a platform. The dominant limb,the preferred kicking limb, of the participant was aligned with the axis of the dynamometer (neutral position- $0^{\circ}$ ) and attached to the footplate with velcro straps. The untested leg hung freely. All participants were tested barefoot and wore shorts to eliminate additional afferent feedback. All participants were instructed about the procedure before the test was demonstrated to familiarize participant with the process. In the familiarization trials, a participant's foot was passively moved to $10^{\circ}$ or $20^{\circ}$ of inversion, randomly, from the neutral start position. Participants were asked to focus on that position for 5 seconds before the foot was passively returned the start position. This familiarization was performed three times. In the test trials, participants were asked to push a stop trigger when they thought the test position had been reached. The speed of the dynamometer was set at $2^{\circ}$ per second. The amount of error (degrees), in the participants' ability to match the target angle, was recorded for each test trial. The same procedures were performed for both inversion angles and a total of three trials for each test position were performed with participants blindfolded. If a participant failed to press the trigger, the device was programmed to stop prior to the participants full range of motion so that no injury occured (Figure 1). 
The same procedure and device were used to assess knee joint position sense with the target angles set at $30^{\circ}$ and $45^{\circ}$ of knee flexion. These positions where chosen because of the sensitivity of the positions at detecting proprioceptive deficits between healthy and injured individuals 22. All participants were instructed about the procedures before the task was demonstrated to familiarize participants with the process. The starting position was set as $90^{\circ}$ of knee flexion and participants underwent 3 familiarization trials as described above. Three test trials were then conducted for each target angle as described above (Figure 2). All assessments were conducted in a quiet environment with no distractions. Testing joint and test angles were randomized to eliminate to contribution of any practice effect.

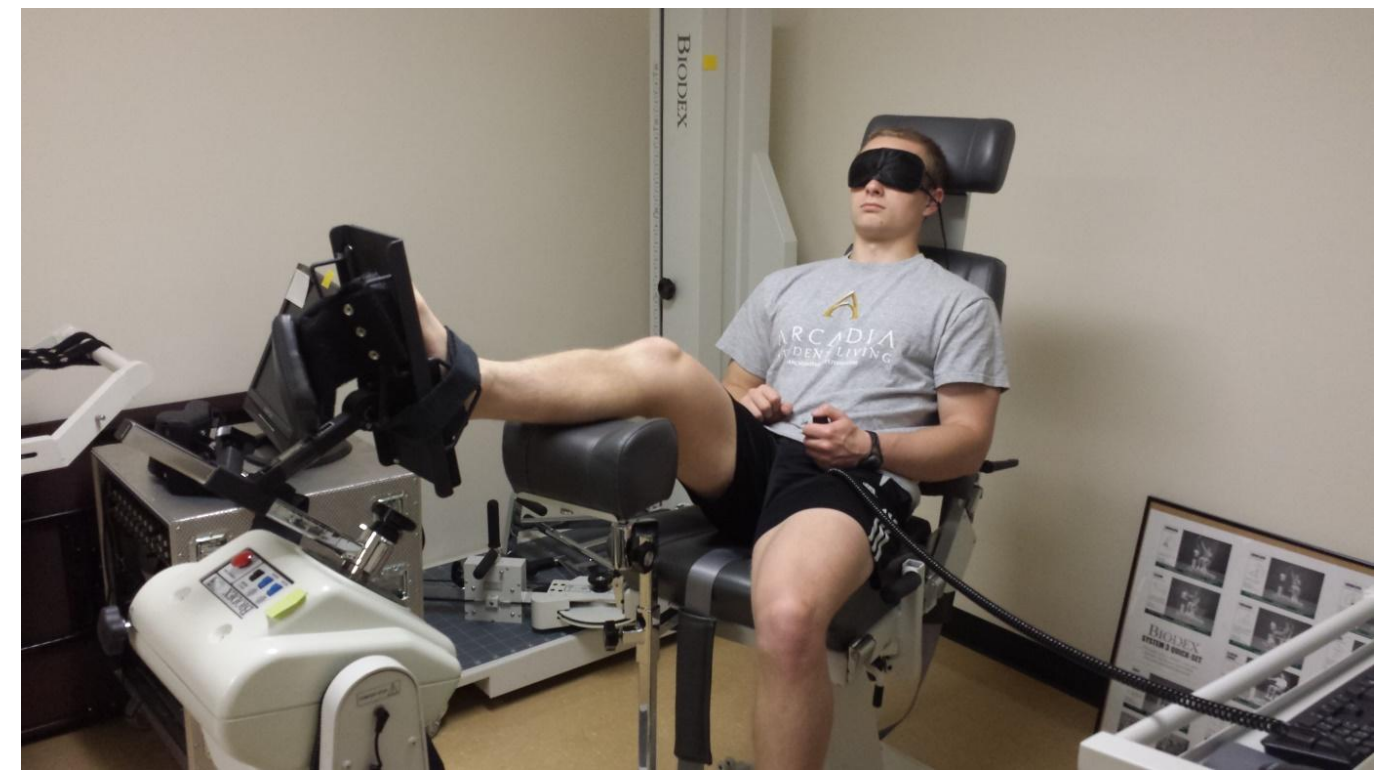

Figure 1. Ankle joint proprioception assessment

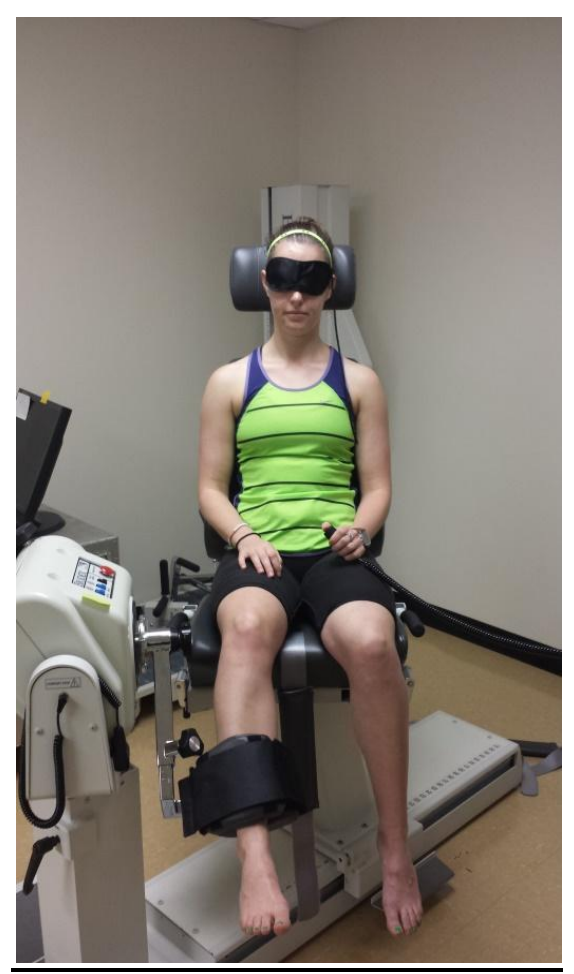

Figure 2. Knee joint proprioception assessment 


\section{Balance Training Intervention}

All participants underwent a total of 12 supervised training sessions over a 4 -week period of time with each session lasting about 30 minutes which described in detailed Cug et al' s study ${ }^{21}$. The balance training program used in the current investigation was a modification of the program initially described by McKeon et al ${ }^{23}$ and described previously ${ }^{21}$. The specific exercises that were performed during each training session included: 1) hop to stabilization onto and off of a BOSU ball in four directions (anterior, lateral, anteriomedial, and anteriolateral; 2) mini-squats on a BOSU ball while in a single limb stance; 3) unanticipated reach sequences while stabilizing on a BOSU ball in a single limb stance; and 4) static single limb stance on a BOSU ball (Figure 3). A brief description of each exercise, the required number of repetitions per training session, and the progression of difficulty levels has been reported by $\mathrm{Cug}$ et al ${ }^{21}$. Participants retuned for posttesting within 48-hours following completion of the $12^{\text {th }}$ training session.
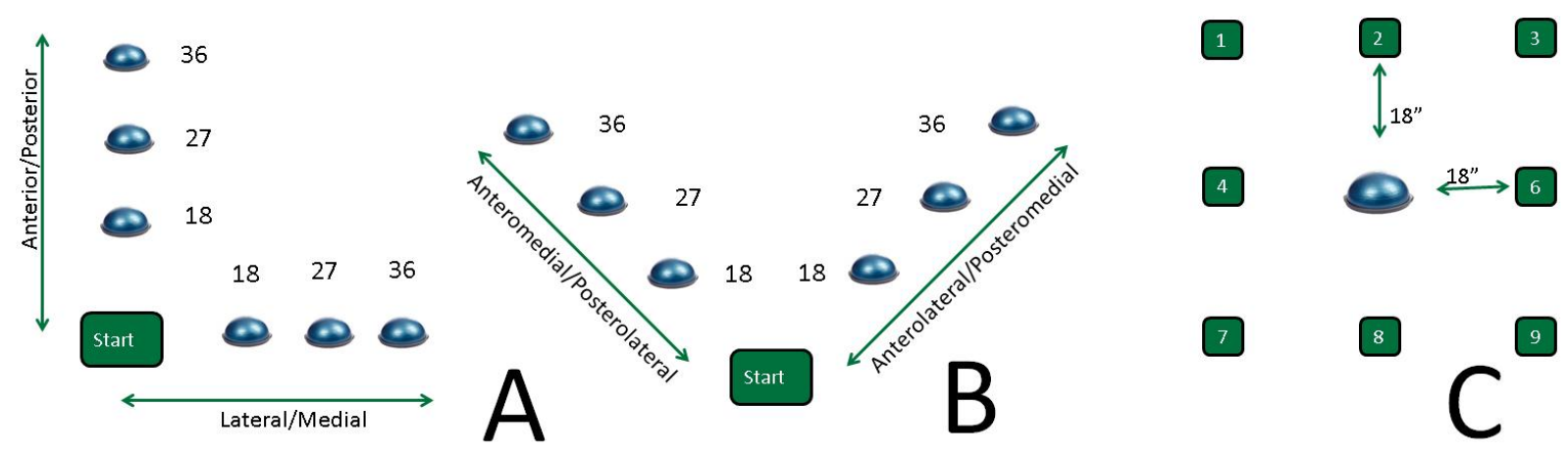

Figure 3. A-B: Hopping directions for the hop to stabilization onto a BOSU Ball. Directions are right-foot oriented. C: Number grid used for the Unanticipated Reach While Stabilizing on a BOSU Ball (Cug,Duncan, Wikstrom, 2016; McKeon 2008)

\section{Statistics}

Averaged absolute error of the test trials for the dominant limb quantifed joint-position sense. Absolute error assigns a positive value to errors; it is the difference between the target angle and the participant's estimated angle without examining the direction of error (ie, underestimation or overestimation). Joint position sense outcomes were submitted to separate dependent sample Ttests to determine the effect of Time (Pre and Post). An a priori alpha level of 0.05 was used to determine statistical significance. Hedges g effect sizes and 95\% confidence intervals were then calculated to provide clinical meaningfulness to the pre to post changes. Effect sizes were interpreted (small $=<0.4$, medium $=0.41$ to 0.7 , large $=>0.70$ ) according to Cohen.

\section{RESULTS}

Means, standard deviations, $\mathrm{p}$ values, and pre to post effect sizes with associated $95 \%$ confidence intervals can be seen in Table 1. Absolute error decreased for $10^{\circ}$ of inversion and $30^{\circ}$ and $45^{\circ}$ of knee flexion despite the lack of significant differences and small effect sizes with $95 \%$ CIs crossed 0 .

Table 1: Means, standard deviations, $\mathrm{p}$ values, and pre to post absolute error effect sizes.

\begin{tabular}{lllll}
\hline Proprioception $\left(^{\circ}\right)$ & Pre Test & Post Test & P value & Effect size (95\% CI) \\
Ankle at $10^{\circ}$ Inversion & $2.29 \pm 1.61$ & $2.09 \pm 1.86$ & 0.635 & $0.09(-0.43$ to 0.61$)$ \\
Ankle at $20^{\circ}$ Inversion & $2.27 \pm 1.66$ & $2.44 \pm 1.17$ & 0.646 & $-0.08(-0.60$ to 0.45$)$ \\
Knee at $30^{\circ}$ Flexion & $5.07 \pm 2.78$ & $4.80 \pm 2.55$ & 0.673 & $0.08(-0.45$ to 0.59$)$ \\
Knee at $45^{\circ}$ Flexion & $4.12 \pm 2.19$ & $3.87 \pm 2.25$ & 0.711 & $0.07(-0.45$ to 0.59$)$ \\
\hline
\end{tabular}




\section{DISCUSSION}

The purpose of this study was to test the effect of dynamic balance training on ankle and knee joint position sense. The current results show that 4 weeks of a dynamic balance training program that emphasizes hop stabilization is not effective at improving ankle or knee joint position sense.

Our choice of using a sample of healthy volunteers, while not inconsistent with the literature, may have impacted our ability to observe significant improvements. Relative to those with musculoskeletal injuries, healthy volunteers should have an intact and functioning sensorimotor system which may have made it harder for measurable differences to have been elucidated.

Another factor that may influence the effectiveness of balance training at improving joint position sense is the type of exercises used in the balance training program. Balance exercises are often described as static or dynamic but dynamic exercises should also be described as impact (e.g. landing and stabilizaing) or nonimpact (e.g. reaching tasks).

Dynamic landing exercises, require eccentric contractions $^{24}$ and such contractions may actually lead to proprioceptive disturbances. ${ }^{25}$ Agonist and antagonist muscle co-contractions are common in dynamic activities and result in increase joint stifness as a result of the rapid stretching of the muscle spindles. ${ }^{20}$ The preparatory muscle activity generated as part of feed-forward neuromuscular control also increase joint stiffness. Previously, $\mathrm{Fu}$ and Hui- $\mathrm{Chan}^{20}$ reported that increased joint stiffness is correlated with poor proprioceptive accuity. Thus, dynamic stabilization may not provide the appropriate environment to train peripheral proprioceptors to improve their fidelity for use in either feedforward or feedback neuromuscular control. Interestingly, Riberio et $\mathrm{al}^{26}$ showed that knee joint position sense was less accurate and less consistent in elite female volleyball players after a match. Previous research has also shown that force sense, joint position sense, and threshold to detect passive movement at the knee are all disrupted after a singular bout of eccentric exercise. ${ }^{27}$ It is extremely possible these results were due to fatigue and or delayed onset muscle soreness. However, Vila-Chã et $\mathrm{al}^{28}$ noted that eccentric exercise impaired non-weight bearing knee proprioception for at least 24-hours following eccentric contractions. Interestingly, the negative effect was not observed during weight-bearing joint position sense testing, further highlighting the need to assess the sensory receptors stressed during a given activity/intervention. In the present study post test assessments of joint position sense were completed within- 48 hours of the final training session. While participants did not report delayed onset muscle soreness, we speculate that our posttest time frame may have been influenced by the lingering effects of the eccentric contractions associated with our balanc training exercises.

Given the potential negative impact of dynamic exercises on proprioception, static postural control exercises may better promote joint position sense. For example, Waddington et $\mathrm{al}^{19}$ compared the effect of a non-impact (wobble board) and impact training (jump landing) program on ankle/knee movement discrimination and noted that 8 weeks of dynamic wobble board exercises result in better ankle joint position sense and movement discrimination but no differences were noted between the training groups for the knee joint.

It is also possible that the training volume played a role in the lack of significant improvements. The existing literature indicates that at least 4weeks of balance training is needed to improve postural control but such training volume criteria are not currently available for joint position sense outcomes. ${ }^{29}$ The current intervention required 3, 30 minutes sessions per week for 4 weeks (360 total minutes) but failed to improve absolute errors scores at the knee or ankle. Previous research appears to suggest that longer training durations may cause improvements in ankle and knee joint position sense. For example Cug et al ${ }^{13}$ found that dynamic non-impact balance training 3 times a week for 10 weeks, improved knee joint position sense by using a passive reproduction of passive positioning protocol in those with healthy people. Similarly, Panics et a ${ }^{14}$ found that training twice a week for an entire season (approximately 25 weeks) also improved knee joint active positioning sense but the exact total volume or average weekly training volume was not reported. Interestingly, relatively short balance training durations (6 weeks), which included non-impact static and dynamic exercises, with low training frequency (as low as once a week), and moderate durations (20 minutes) have also resulted in improved ankle joint position sense in those with chronic ankle instability. ${ }^{15}$ However, Bernier and Perrin $^{16}$ noted that 6 weeks of balance \& coordination training ( 3 weeks per week, 10 minutes per session, mainly non-impact, both 
static and dynamic balance exercises) failed to improve ankle proprioception assessed by passive joint repositioning. Cumulatively, it appears that larger training durations may improve the probability of seeing joint position sense improvements but the results are not unaniomus as differences in samples used and testing methodology may also play a role.

Joint position sense is typically measured in a nonweightbearing position ${ }^{16}$ despite balance training interventions requiring sensory input during weight bearing activities (single limb stance). During non-weight bearing tests, muscles are not active resulting in decreased fusimotor activity and diminished sensory feedback from muscle spindles. Similarly, input from plantar cutaneous receptors appears to play a strong role in sensory feedback ${ }^{30}$ and this input would not be assessed during a nonweightbearing assessment of joint position sense. On the other hand, previous research has shown that during weightbearing tests, knee extension and ankle dorsiflexion stretch the calf muscles. These motions enhance input from intramuscular stretch receptors and have a secondary effect on plantar cutaneous receptors and adjacent mechanoreceptors (e.g. ankle capsular receptors and/or receptors in the shank muscles) ${ }^{31}$. This apparent disconnect between receptors stressed during training and those assessed during testing may also contribute to the lack of improvements in the current study and the mixed results in the the existing literature 18,28 .

The following clinical implications should be suggested 1-) Longer training durations may cause improvements in ankle and knee joint position sense, 2-) Given the potential negative impact of dynamic exercises on proprioception, dynamic non-impact type balance exercises may better promote joint position sense, 3-) Post assessments can be perfomed not only immediately after exercise but also in certain time periods such as 3-5-7 days later after completing the last exercise session.

In conclusion, despite seeing decreases in absolute error for $10^{\circ}$ of inversion, $30^{\circ}$ and $45^{\circ}$ of knee flexion, the dynamic balance training program with an emphasis on stabilization tasks using an unbalanced surface did not statistically change joint position sense for the knee or ankle. It is suggested that dynamic non-impact type balance training with longer duration may have positive affect on ankle and knee joint position sense.

\section{REFERENCES}

1. PETERSON LR, Per AFH. Sports Injuries: Prevention, Treatment and Rehabilitation: CRC Press; 2016.

2. Kemler E, van de Port I, Schmikli S, Huisstede B, Hoes A, Backx F. Effects of soft bracing or taping on a lateral ankle sprain: a non-randomised controlled trial evaluating recurrence rates and residual symptoms at one year. J Foot Ankle Res. $2015 ; 8$.

3. Pierpoint LA, Kerr ZY, Currie DW, Comstock DR. Epidemiology of Knee Sprains in Us High School and Collegiate Athletics. Injury Prev. 2016;22:A149-a.

4. Gribble PA, Bleakley CM, Caulfield BM, Docherty CL, Fourchet F, Fong DTP, et al. Evidence review for the 2016 International Ankle Consortium consensus statement on the prevalence, impact and long-term consequences of lateral ankle sprains. British Journal of Sports Medicine. 2016;50(24):1496-+.

5. Murphy DF, Connolly DAJ, Beynnon BD. Risk factors for lower extremity injury: a review of the literature. British Journal of Sports Medicine. 2003;37(1):13-29.

6. Anandacoomarasamy A, Barnsley L. Long term outcomes of inversion ankle injuries. British Journal of Sports Medicine. 2005;39(3).

7. Baltaci G, Kohl HW. Does Proprioceptive Training During Knee and Ankle Rehabilitation Improve Outcome? Physical Therapy Reviews. 2003;8:5-16.

8. McKeon JMM, McKeon PO. Evaluation of joint position recognition measurement variables associated with chronic ankle instability: a metaanalysis. Journal of athletic training. 2012;47(4):444.

9. Lephart SM, Pincivero DM, Giraldo JL, Fu FH. The role of proprioception in the management and rehabilitation of athletic injuries. American Journal of Sports Medicine. 1997;25(1):130-7.

10.Maior AS, Simão, R., Salles, B.F., Miranda,H., Costa, P.B. Neuromuscular activity during the squat exercise on an unstable platform. Brazilian Journal of Biomotricity. 2009;3(2):121-9.

11.Kiers H, Brumagne S, van Dieen J, van der Wees P, Vanhees L. Ankle proprioception is not targeted by exercises on an unstable surface. European Journal of Applied Physiology. 2012;112(4):1577-85. 
12.Eils E, Schroter R, Schroder M, Gerss J, Rosenbaum D. Multistation Proprioceptive Exercise Program Prevents Ankle Injuries in Basketball. Medicine and Science in Sports and Exercise. 2010;42(11):2098-105.

13.Cug M, Ak E, Ozdemir RA, Korkusuz F, Behm DG. The effect of instability training on knee joint proprioception and core strength. Journal of Sports Science and Medicine. 2012;11(3):468-74.

14.Panics G, Tallay A, Pavlik A, Berkes I. Effect of proprioception training on knee joint position sense in female team handball players. British Journal of Sports Medicine. 2008;42(6):472-6.

15.Eils E, Rosenbaum D. A multi-station proprioceptive exercise program in patients with ankle instability. Medicine and science in sports and exercise. 2001;33(12):1991-8.

16.Bernier JN, Perrin DH. Effect of coordination training on proprioception of the functionally unstable ankle. Journal of Orthopaedic \& Sports Physical Therapy. 1998;27(4):264-75.

17.Holm I, Fosdahl MA, Friis A, Risberg MA, Myklebust G, Steen H. Effect of neuromuscular training on proprioception, balance, muscle strength, and lower limb function in female team handball players. Clinical Journal of Sport Medicine. 2004;14(2):88-94.

18.Riemann BL, Tray NC, Lephart SM. Unilateral multiaxial coordination training and ankle kinesthesia, muscle strength, and postural control. Journal of Sport Rehabilitation. 2003;12(1):13-30.

19. Waddington G, Seward H, Wrigley T, Lacey $\mathrm{N}$, Adams R. Comparing wobble board and jumplanding training effects on knee and ankle movement discrimination. Journal of Science and Medicine in Sport. 2000;3(4):449-59.

20.Fu SN, Wan C, Ying HC. Are there any relationships among ankle proprioception acuity, pre-landing ankle muscle responses, and landing impact in man? Neuroscience Letters. 2007;417(2):123-7.

21.Cug M, Duncan A, Wikstrom E. Comparative Effects of Different Balance-Training-Progression Styles on Postural Control and Ankle Force Production: A Randomized Controlled Trial. Journal of Athletic Training. 2016;51(2):101-10.

22.Kramer J, Handfield T, Kiefer G, Forwell L, Birmingham T. Comparisons of weight-bearing and non-weight-bearing tests of knee proprioception performed by patients with patellofemoral pain syndrome and asymptomatic individuals. Clinical Journal of Sport Medicine. 1997;7(2):113-8.

23.McKeon P, Ingersoll C, Kerrigan DC, Saliba E, Bennett B, Hertel J. Balance training improves function and postural control in those with chronic ankle instability. Medicine+ Science in Sports+ Exercise. 2008;40(10):1810.

24.Horita T, Komi PV, Nicol C, Kyrolainen H. Interaction between pre-landing activities and stiffness regulation of the knee joint musculoskeletal system in the drop jump: implications to performance. European Journal of Applied Physiology. 2002;88(1-2):76-84.

25.Saxton JM, Clarkson PM, James R, Miles M, Westerfer M, Clark S, et al. Neuromuscular Dysfunction Following Eccentric Exercise. Medicine and Science in Sports and Exercise. 1995;27(8):1185-93.

26.Ribeiro F, Santos F, Goncalves P, Oliveira J. Effects of volleyball match-induced fatigue on knee joint position sense. European Journal of Sport Science. 2008;8(6):397-402.

27.Torres R, Vasques J, Duarte JA, Cabri JMH. Knee Proprioception after Exercise-Induced Muscle Damage. International Journal of Sports Medicine. 2010;31(6):410-5.

28.Vila-Cha C, Riis S, Lund D, Moller A, Farina D, Falla D. Effect of unaccustomed eccentric exercise on proprioception of the knee in weight and non-weight bearing tasks. Journal of Electromyography and Kinesiology. 2011;21(1):141-7.

29.Zech A, Hubscher M, Vogt L, Banzer W, Hansel F, Pfeifer K. Balance Training for Neuromuscular Control and Performance Enhancement: A Systematic Review. Journal of Athletic Training. 2010;45(4):392-403.

30.Han J, Waddington G, Adams R, Anson J, Liu Y. Assessing proprioception: A critical review of methods. J Sport Health Sci. 2016;5(1):80-90.

31.Refshauge KM, Fitzpatrick RC. Perception of Movement at the Human Ankle - Effects of Leg Position. Journal of Physiology-London. 1995;488(1):243-8. 